\title{
The Contaminated Milk Affair
}

Frédéric Keck

\section{OpenEdition}

\section{Journals}

Electronic version

URL: http://journals.openedition.org/chinaperspectives/4780

DOI: $10.4000 /$ chinaperspectives. 4780

ISSN: 1996-4617

\section{Publisher}

Centre d'étude français sur la Chine contemporaine

\section{Printed version}

Date of publication: 1 April 2009

Number of pages: 88-93

ISSN: 2070-3449

\section{Electronic reference}

Frédéric Keck, «The Contaminated Milk Affair », China Perspectives [Online], 2009/1 | 2009, Online since 01 April 2011, connection on 15 September 2020. URL : http://journals.openedition.org/ chinaperspectives/4780 


\section{( $)$}

\section{The Contaminated Milk Affair}

FRÉDÉRIC KECK

$\mathrm{T}$ he scandal following the revelation of the use of melamine, which causes acute kidney problems, in the production of milk powder created one of the greatest health crises in contemporary China. Since the SARS epidemic in 2003, the Chinese government has been particularly keen to deal with such questions in the field of public health. ${ }^{(1)}$ This has given the population at large an opportunity to voice their legitimate concerns, usually forbidden in the strictly political field, by raising the question of responsibility at the highest levels. How could the Chinese government have allowed such a toxic contaminant to enter the supply lines of the milk trade? The foreign media seized on the affair to make a further dig at the "Made in China" label, which had already been damaged by a scandal over lead-tainted Mattel toys. Internationally, the criticism was no longer levelled at the government alone, but at the whole culture of fraud in China.

This crisis, in its general outlines, in the course of its development, and in the breadth of its potential consequences, is very similar to the "contaminated blood affair" that shook the socialist government in France in the early 1990s and led to one of the most notorious trials of the Fifth Republic. ${ }^{(2)}$ But we know that similar contamination occurred in the blood transfusion and distribution channels in Henan Province without that local scandal leading to a full-blown affair involving accusations against the political leadership. ${ }^{(3)}$ The real question, therefore, should not be put in terms of immediate emotional response from the public, but at quite a different level. How could an apparently minor industry in China (the manufacture of milk products) have led to a health crisis, while revelations concerning contaminated blood had no such effect?

The following argument is based on my reading of articles about the scandal, from its uncovering in September 2008 to the trial of the Sanlu directors in January 2009, and on an anthropological hypothesis that has been tested in the light of other health crises. My main sources are reports in the South China Morning Post (SCMP) throughout the period in question, supplemented by several opinion polls in the French and Chinese media. These reveal three separate stages: the uncovering of the scandal, the enquiry into food safety standards, and the problematic legal resolution.

\section{The scandal is uncovered}

Every health crisis begins with a whistleblower. ${ }^{(4)}$ In the case of the contaminated milk affair, this role was played by the Fonterra milk products company. On 5 September 2008, this Auckland-based company informed the New Zealand government that there were health problems linked to the powdered milk produced by China's Sanlu Group, in which it held 43 percent of the shares: more than a thousand children had developed kidney stones after ingesting the product, and two babies had died. Helen Clark, the Prime Minister of New Zealand, responded by requesting that the Chinese government withdraw the defective products from the market. ${ }^{(5)}$ In fact, this public revelation at the highest level had followed a whole series of unsuccessful warnings. Back in March 2008, some consumers had complained that their children were falling ill after being fed Sanlu powdered milk, and many blogs had spread that information. On 2 August, Fonterra had warned the city authorities in Shijiazhuang, where the Sanlu company is based, of the need to recall the products. It was only when the scandal erupted on the international scene, however, that it had any repercussions in China. In the week following the alert on 5 September, the scandal escalated to ever higher levels until the Ministry of Health forced Sanlu to recall all its products. ${ }^{(6)}$

1. See Alain Guilloux's summaries of publications on this question in Perspectives Chinoises nos. 92 and 99, and my own in the 2007/4 issue.

2. In the French and English language media, the milk was referred to as "contaminated" just as frequently as "tainted." The former expression had the advantage of not insisting so much on the more or less intentional causes behind the poisoning as on its effects, which extend to the "contamination" of every aspect of social life. That is why this article retains the same term.

3. On the distinction between a scandal and an affair, see Luc Boltanski, Elisabeth Claverie Nicolas Offenstadt, and Stéphane Van Damme, Affaires, scandales et grandes causes: de Socrate à Pinochet, Paris, Stock, 2007. There is a scandal when the media seize on an issue to present it to public opinion and denounce an injustice; this becomes an "affair" when this cause manages to involve an increasing number of active supporters, leading to a trial in which they are all in the limelight (such as in the "Dreyfus affair").

4. See F. Chateauraynaud and D. Torny, Les Sombres Précurseurs: une sociologie pragmatique de l'alerte et du risque, Paris, EHESS, 1999.

5. On the strategies of companies that decide to withdraw their products in the face of a health crisis, see J. Besançon, 0. Borraz, and C. Grandclément-Chaffy, La sécurité alimentaire en crises: les crises Coca-Cola et Listeria en 1999-2000, Paris, L'Harmattan, 2004.

6. South China Morning Post (hereafter SCMP), 17 September 2008, "Officials knew of tainted milk for a month." 
At that point, the Chinese and international media began to raise questions about the nature of the toxic element in the powdered milk. ${ }^{(7)}$ Melamine is a chemical compound $(\mathrm{C} 3 \mathrm{H} 6 \mathrm{~N} 6)$ derived from urea. Developed during the 1930s, it possesses a number of properties that make it indispensable to industry, particularly in the production of plastics. It is present in very low doses in all drinks on the market through transmission from plastic containers to their contents. It is only when high doses are taken regularly that it can badly affect the kidneys, however, because in low doses it is easily eliminated. Since China is the largest melamine producer in the world, it is easy to see how excess production could find a ready outlet in the milk industry; milk producers had become accustomed to diluting their products with water, and melamine has the effect of boosting the protein content in products being tested. This can certainly be considered fraudulent, because melamine does not increase the real nutritional value, but only the value measured by the tests. Paradoxically, therefore, it was milk products with the "highest nutritional content," recommended for children suffering from malnourishment, that caused the cases of poisoning. ${ }^{(8)}$

The enquiry quickly revealed that the fraudulent use of melamine was not restricted to the Sanlu Group, but was common throughout China's milk products industry due to its close relations with other industries. ${ }^{(9)}$ The responsibility was first laid at Sanlu's door, but it subsequently spread to everyone in the chain of milk production. In the localities, police caught milk producers in the act of adding melamine. ${ }^{(10)}$ Sanlu director Ms. Tian Wenhua resigned, as did the vice-mayor of Shijiazhuang, Zhang Fawang. The leaders of the major Chinese milk formula companies (Mengniu and Yilin) mounted large public milk-drinking ceremonies in order to restore consumer confidence, while they begged forgiveness for not noticing the acts of fraud. ${ }^{\text {(II) The }}$ director of the Administration of Quality Supervision, Inspection and Quarantine (AQSIQ), Li Changjiang, was forced to resign. ${ }^{(12)}$ In Taiwan, the import of Chinese products raised sensitive questions. The Health Minister resigned, and his successor was vehemently denounced by demonstrators. ${ }^{(13)}$ And at the international level, the organisation Reporters Sans Frontières accused the director of the World Health Organisation (WHO), Margaret Chan, who had handled the avian flu and SARS crises at the Department of Health in Hong Kong, of covering up the scandal on behalf of the Chinese government. The WHO replied that it had no control over milk products, ${ }^{(14)}$ and went on to criticise the outdated food safety provisions in
China. ${ }^{(15)}$ More recently, a petition signed by Chinese lawyers and academics criticised the official television channel CCTV for helping to suppress news of the melamine scandal. By then, the contaminated milk scandal was involving too many players in the blame game; it was time to call in the experts.

\section{The enquiry into food safety}

Just as the Chinese government had deployed an impressive arsenal in its fight against the SARS virus, so its public acknowledgement of the contaminated milk crisis led to a huge melamine hunt across the whole country. But in their efforts at damage control, the experts uncovered the full extent of the problem. The first need was to manage the large influx of parents bringing an increasing number of poisoned children into the hospitals. The experts had no idea of the effects of melamine on the human body, or of the best methods of treatment, since previous experiments involving the administration of large doses had only been conducted on rats. ${ }^{\left({ }^{(1)}\right)}$ All they could do was recommend rest while waiting for the kidneys to eliminate the toxins. The next need was to test all foodstuffs containing milk; but as food safety tests had never been used to test for melamine, the safety inspections office had to introduce a new range of inspection procedures, ${ }^{(17)}$ and these revealed the full extent of the contamination. Out of 491 samples of powdered milk from 109 milk product firms, 69 contained varying doses of melamine. ${ }^{(18)}$ Then Starbucks announced the withdrawal of

7. At first the French media tended to mentioned "melanin," a mildly toxic product found in suntan cream.

8. www.cite-sciences.fr : "Mélamine: Retour sur le scandale du lait frelaté." No French reader could fail to notice the similarity with the growth hormones affair, which had legal proceedings taking place in France at the same time.

9. In an interview published by the journal Science on 17 October 2008, Premier Wen Jiabao declared that "Although problems occurred at the company, the government also has a responsibility. (...) It is absolutely impermissible to sacrifice people's lives and health in exchange for temporary economic development. Food, all food, must meet international standards."

10. SCMP, 30 September 2008, "Police in Hebei seize melamine in farm raids"; SCMP, 11 October 2008: "Key melamine producer arrested in Hebei," and "Punishment up to death for breaking dairy laws."

11. SCMP, 20 September 2008, "Shanghai dairy giant apologises."

12. SCMP, 23 September 2008 , "Milk scandal fells product safety chief."

13. SCMP, 4 October 2008, "Taiwanese health minister resigns after lawmakers' fracas over milk scare."

14. Aujourd'hui la Chine, 3 October, 2008, "RSF accuse l'OMS de légèreté dans le scandale du lait en Chine."

15. SCMP, 23 October 2008, "WHO criticises food safety system."

16. SCMP, 21 November 2008 , "No consensus on treating kidney stones in infants."

17. SCMP, 9 0ctober 2008, "The probability gap."

18. SCMP, 17 September 2008 , "Tests find tainted baby milk at 21 more firms." 
all milk products from their outlets, and the substitution of soya milk ${ }^{(19)}$ - before further tests showed that soya might also contain melamine. ${ }^{(20)}$ In late November, the US Food and Drug Administration offered expert help to the Chinese government after discovering excessive quantities of melamine (over one part per million) in the products of three leading firms: Abbott, Nestlé, and Mead Johnson. ${ }^{(21)}$ The British company Cadbury recalled 11 of its products manufactured in China after conducting its own tests but without making the results public. ${ }^{(22)}$

Hong Kong resumed the role of public health defender that it had played during the SARS crisis, through recourse to the institutions it had established at that time. The Centre for Health Protection attempted to relieve the threat of overcrowding in Chinese hospitals by designating 18 clinics for kidney examinations, and by setting up a hotline, which received more than 10,000 calls. ${ }^{(23)}$ It uncovered thirteen suspected cases, but no instances of mortality. The Centre for Food Safety tested all milk products imported from China to see whether they exceeded the limit of 2.5 parts per million adopted by the Hong Kong government at the beginning of the crisis. It discovered excessive melamine in Mai-lai, a popular dessert sold in Maxim's outlets, and in a yoghurt ice cream made by Yili. But by launching such an enquiry, the Hong Kong government set off another alarm. On 25 October, the Centre for Food Safety announced that some eggs imported from Dalian had shown positive results in tests for melamine. ${ }^{(24)}$ Given Hong Kong's permanent state of alert against avian flu over the previous decade, this contamination in chicken farms could only raise further suspicion. ${ }^{(25)}$ The issue of live poultry farms, which is very sensitive in Hong Kong, gave rise to a disagreement with the Chinese government over the best methods for testing chickens. ${ }^{(26)}$ Other tests were carried out on fish, and they produced negative results despite the presence of melamine in the food used in fish farms. ${ }^{(27)}$ In the $S C M P$ letter columns, a biochemistry professor at the City University voiced his worries about the presence of melamine in pork, the principal meat consumed in China, but no official test confirmed his suspicions.

The detection of melamine in eggs showed that the contamination was not restricted to babies' milk formulae but affected the entire food chain, and especially animal feed. ${ }^{(28)} \mathrm{It}$ was then recalled that in the US in 2007 an excessively high death rate among dogs was linked to the presence of melamine in dog food, and this, compounded by accusations of corruption, had led to the execution of the director of the Administration of Quality Supervision, Inspection and
Quarantine. This revelation coincided with a rumour spread on the Internet criticising the dual system in the Chinese milk trade: a separate "special food distribution centre belonging to the State Council" was alleged to enable leading Chinese functionaries to consume products free of all contamination. " ${ }^{(29)}$ In Hong Kong, shops selling milk products imported from abroad (particularly from Australia and New Zealand) experienced increased sales. In Europe, people noted with relief that Chinese milk imports had been forbidden since 2002, and that only Bangladesh, Burma, and Yemen imported any at all. ${ }^{(30)}$

These revelations suggest that contaminated milk may have been channelled towards "second class" populations. China was also strongly suspected of concealing complaints from the parents of sick children in the run-up to the Olympic Games, in order to present the image of a "harmonious society" and to avoid worrying athletes over the quality of the food they were given. But with the end of the Olympic Games, the contaminated milk affair demonstrated once again the deep inequalities that divide Chinese society. The recourse to legal action presented opportunities for denouncing these divisions.

\section{Resolving the crisis through legal means?}

The trial of Tian Wenhua, which opened on 26 December 2008 in Shijiazhuang, is considered by many observers to have focused on a scapegoat. This 67-year-old director of Sanlu is described as a model family woman known for her

19. SCMP, 20 September 2008, "Milk coffees off the menu at Starbucks - try soya."

20. SCMP, 4 October 2008, "Minister cites fast expansion as scandal touches soya milk."

21. SCMP, 27 November 2008, "Traces of Melamine found in US formula"; and 30 November 2008, "US sets limit for melamine in baby milk."

22. SCMP, 21 December 2008, "Cadbury recalls 11 products after tests reveal melamine."

23. SCMP, 23 September 2008, "Frustrated parents clamour for help as hospital battles to cope."

24. SCMP, 28 October 2008, "Boss of Dalian firm apologises over tainted eggs sent to HK."

25. On 10 December 2008, an outbreak of avian flu was declared on a Hong Kong farm, the first since 2003. The newspapers suspected that the virus had been spread by eggs smuggled in from China.

26. SCMP, 5 November 2008, "HK, Mainland bodies clash on melamine tests."

27. SCMP, 28 November 2008, "Melamine in fish food — but not in fish."

28. See Le Monde, 30 October 2008, "Suspicion spreads to the entire food chain." In a study published by the Chinese CDC, out of a sample of 2,000 children in Gansu, $17 \%$ were suffering from kidney problems, and $10 \%$ of those children had never drunk milk from Sanlu milk powder, which suggests another source of contamination. Cf. SCMP, 21 November 2008, "Kidney stone risk 30 times higher in China."

29. http://caichongguo.blog.lemonde.fr/2008/09, "An internal network for distributing foodstuffs to leading functionaries has been revealed."

30. See www.afssa.fr, 2 December 2008, "Melamine and food products." 
kindness and modesty. A former veterinary practitioner, she managed in the course of 20 years to transform a small farm into a leading profitable enterprise, eventually becoming the chairperson of the Chinese Milk Industries Association. In December, the Chinese government announced that melamine contamination had killed six children and poisoned 300,000 more. The charge of the "manufacture and sale of dangerous toxic food products" was replaced by the "manufacture and sale of defective products," which spared Tian from facing the death penalty. Another 20 people faced the same charges, including three members of the Sanlu board, and six were accused of having produced and sold "powdered protein" containing melamine. ${ }^{(31)}$ The court also considered Sanlu's application for bankruptcy, which was filed on 24 December. The prosecutor went over the various warnings received by the enterprise from the beginning of 2008: an internal investigation team had been set up on 20 May, but on 13 August the board had decided to sell products in which melamine had been detected. Tian Wenhua pleaded guilty, but stated that she had informed the local authorities. In fact, a meeting with the mayor of Shijiazhuang on 2 August had led to the recall of the dangerous products being postponed until after the Olympic Games. ${ }^{(32)}$

However, the Shijiazhuang trial did not put an end to the anger of the families, who were not allowed to attend. Since the beginning of the crisis, the provincial authorities had discouraged lawyers from representing the parents of the poisoned children. ${ }^{(33)}$ Local health offices had resisted registering children's deaths as caused by the ingestion of milk powder. In Hubei, doctors attributed a child's death to inflammation of the heart, and refused to carry out an autopsy for which the parents, being migrant workers, were unable to pay. ${ }^{(34)}$ Families of children registered as cases of melamine poisoning are entitled to substantial compensation, even if the payments are not quite as high as their initial demands. On 14 January 2009, the village couple from Gansu whose child had died on 1 May 2008 and had become the first officially recognised fatality, received 200,000 yuan from Sanlu on the condition that they renounce all further claims. On 5 May 2008 they had sued Sanlu for 1 million yuan, but that claim had been thrown out. ${ }^{(35)}$ Sanlu also offered 200,000 yuan to other parents whose children had died from milk powder poisoning, 30,000 yuan to those whose children were badly affected, and 2,000 yuan to those with lesser complaints. The firm's bankruptcy application on 24 December, however, cast doubts on the likelihood of that compensation ever being paid. ${ }^{(36)}$ More than 500 families of affected children decided to seek damages through the People's Supreme Court in Beijing, demanding long-term treatment for their children instead of immediate pay-outs, ${ }^{(37)}$ but the local authorities prevented the parents of sick children from going to Beijing to lodge their complaint. ${ }^{(38)}$ If the government was able to promise compensation to foreign companies importing Chinese milk, it could surely bear the costs of meeting the same responsibility towards its own citizens. ${ }^{(39)}$ The legal burdens could be borne by the whole of the chain for milk production and distribution.

\section{The transformation of milk production in contemporary China}

Some reporters travelled to Inner Mongolia to interview milk producers. This is the traditional cattle raising area that supplies the milk for the industries based around Beijing. It has small family-run dairy farms in which working conditions have changed considerably over the last ten years. The Chinese government has given strong backing to milk production by providing subsidies for exports, and this has led to a rise in the price of milk. In the words of Ji Weigui, cited as an example of the newly rich who bought 20 cows to sell on to other villagers, "Farmers know very little about the outside world; when the government told them to raise cattle, they simply did what they were told." According to a Hohhot saying, "Raising one cow will feed the family; two will pay for the children's schooling; and three will give you a new house." Zhang Zilong, who has ten cows, has seen the price of milk rise from 1.6 yuan per kilo in 1993 to its current level of 2.9 yuan. But the profit margin is low (at about 0.2 yuan per kilo of milk sold) because a cow's daily consumption is $15 \mathrm{~kg}$ of factory-produced feed (the price of which has risen from 0.8 yuan per $\mathrm{kg}$ to its current 2 yuan)

31. On 22 January, three of these six were condemned to death, and Tian Wenhua was given a life sentence, without any politician being charged. This confirms yet again the old adage, "Kill the cock to frighten the monkey."

32. Caijing, 15 January 2009, "The Sanlu Trial: Diary of a Dairy Disaster."

33. SCMP, 23 September 2008, "Lawyers warned to shun milk suits."

34. SCMP, 11 December 2008, "Hubei officials deny baby's death linked to tainted formula."

35. Chinaview,16 January 2008, "Parents of dead child accept compensation after China tainted milk scandal."

36. SCMP, 26 December 2008, "Sanlu victims' compensation under threat."

37. Associated Press, 19 January 2009, "213 China families take milk case to highest court."

38. SCMP, 22 January 2009, "Parents detained ahead of verdict in melamine trial."

39. SCMP, 11 0ctober 2008, "Beijing promises to help foreign firms get compensation." 
and $20 \mathrm{~kg}$ of grass (which costs around 0.2 yuan per $\mathrm{kg}$ ). ${ }^{(40)}$ Consequently, there was an acceptance of the practice of setting aside milk with low protein content to have melamine added to it, even though the operation itself was carried out after the milk was passed on from the producer to the industrialist. $^{(4)}$ That is why the decision by the large industrialists to cease purchasing milk for the time being, and to discard the low protein milk, has brought turmoil to this fragile local economy, whose balance was already shifting under the pressures of rising demand.

The contaminated milk affair also throws light on changing patterns among consumers. The poisoned babies tended to be the children of migrant workers, who were given milk made from powder with added nutritional value to compensate for the absence of their mothers. The SCMP did not carry reports about milk feeding practices, but the readers' columns contained several conventional calls for a return to breastfeeding, taking no account of the living conditions of the families implicitly criticised. There was also a startling article announcing that Chinese scientists at the State Biotechnical Laboratory for Agriculture had genetically modified some cows in a way that enabled them to produce a protein normally found only in mother's milk, without incurring the need for chemical additives. ${ }^{(42)}$ This "discovery" has not been followed up.

In his book entitled The Food of China, the anthropologist Eugene Anderson raises the question of why, in the course of their history, the Chinese have developed cattle breeding less than other forms of breeding. He sets aside the often cited biological argument that Chinese do not possess lactase, an enzyme that enables the digestion of milk after weaning. A more sociological argument rests on the Chinese mistrust of the cows of Central Asia, which they associate with the alien and threatening neighbours who own them. He argues that "the Chinese have never been fond of milk products; but from the Wei through to the Tang periods, strong influences from Central Asia made dairy products more widely used. Under the Song dynasty, when the centre of power was in the Southeast (where influences from Central Asia had been minimal) and when the dynasties from the Altaic mountains were considered as enemies, milk products were marks of the barbarian." ${ }^{(43)}$ But Anderson ultimately relies on a third, more ecological, argument: the Chinese give primacy to the raising of pigs and chickens because these require little space and feed on human leftovers, whereas cows are costly in terms of both space and fodder. He argues that "given China's environment, which is not only bad for raising cattle but also for keeping milk even when preserved as yoghurt and cheese, milk processing was too difficult, expensive and dangerous. " ${ }^{(4)}$ So the main aim of those who did raise cattle was to use them for ploughing, and this led to their being represented not as abundant sources of milk and meat, but as faithful working companions, who should not to be eaten. ${ }^{(4)}$

This enables us to understand why the contaminated milk affair triggered such a scandal. The health crisis brought to light a change in the practices of production and consumption, which those involved had been vaguely aware of, but which had not appeared problematic until then. In order for the poisoning of children through the drinking of milk to appear truly "impermissible," to quote Prime Minister Wen Jiabao, there had to be not only the introduction of a toxic agent, but also an existing suspicion about the quality of the product in circulation. The meaning of a health crisis depends on the way in which the poles of production and consumption, already increasingly separated by the industrial system, came to appear as contradictory opposites in the collective modes of representation. The contaminated milk affair achieved such notoriety because the conditions for the production and the consumption of milk in contemporary China (established on the model of the dairy industry in the West, plus the development of milk formula on the basis of the distance of the migrant workers from their children) reawakened traditional suspicions towards milk. This is just a hypothesis, but it might explain why this scandal managed to shake Chinese society at a deeper level than the purely political outrage provoked by its international revelation, even though that was its initial cause. This hypothetical explanation would need to be supported by a study of the particular forms used to express moral outrage, in order to see how they serve to perpetuate the initial political criticism.

A comparison with the infected blood scandal could give further support to this hypothesis. Blood transfusions were considered by the Chinese authorities to be the source of a new kind of profitability and were not regarded with suspicion before the scandal broke. ${ }^{(4)}$ That might be a reason (added the fact that Chinese blood was not sold abroad) why the

40. SCMP, 23 September 2008, "Dairy producers fear dark days ahead in aftermath of scare."

41. SCMP,20 September 2008, "Dirty secret of milk-faking capital."

42. SCMP, 20 0ctober 2008, "Super-cows to give mothers' milk."

43. E. Anderson, The Food of China, New Haven, Yale University Press, 1990, p. 66.

44. Ibid., p. 146

45. See V. Goossaert, L'interdit du boeuf en Chine: Agriculture, éthique et sacrifice, Paris, Bibliothèque de I'Institut des Hautes Etudes Chinoises, 2005.

46. See P. Haski, Le Sang de la Chine, Paris, Grasset, 2005. 
scandal did not reach the proportions of a full-blown affair, and why its development was restricted regionally, being suppressed by the local authorities. In this respect, the situation was the mirror image of that in France. In France, it was the national blood transfusion system that was suspect, as the sale of blood had been introduced under the German occupation, and the Resistance had condemned it by proclaiming the values of voluntary donation. ${ }^{(47)}$ Milk, on the other hand, has been consistently promoted within the policy of state subsidies for cattle farming - allowing the cow to become one of the symbolic animals of rural France. That is why the crisis over mad cow disease was seen in France as a repetition of the contaminated blood affair: the safety measures for the protection of the blood supply simply needed to be transferred to the food chain, which was considered essentially pure. ${ }^{(48)}$ One hopes that in China the reverse phenomenon may occur. The government may be able to strengthen its fight against AIDS on the basis of its mobilisation of resources over the contaminated milk affair. More broadly, it may turn out that the health crises linked to the changes in cattle farming may bring out critical responses already available in Chinese culture, such as the vegetarian values rooted in Buddhism, for example. Therefore, we should not invoke a "culture of secrecy" peculiar to China; every culture produces its health crises in accordance with its economic mechanisms and its collective modes of representation.

\section{- Translated by Jonathan Hall}

47. See M. A. Hermitte, Le sang et le droit: Essai sur la transfusion sanguine, Paris, Seuil, 1996.

48. See M. Hirsch et al., L'affolante affaire de la vache folle, Paris, Balland, 1996.

\section{Chronology of the Contaminated Milk Affair}

\section{The suppression of the scandal:}

March 2008: first complaints from parents of children who had become ill after taking Sanlu milk formula

5 May: first legal action against the Sanlu Group is rejected by the courts

20 May: Sanlu sets up an internal investigation team

2 August: Fonterra informs the Shijiazhuang authorities of the need to withdraw Sanlu milk powder from the market

13 August: Sanlu decides to continue sale of the suspect milk products

\section{The scandal breaks:}

5 September: Fonterra informs the New Zealand government of the health problems linked to Chinese milk

8 September: the Hebei provincial government is informed about the problem

10 September: official Chinese media carry reports about sick babies 11 September: Sanlu recalls all products manufactured before 6 August 13 September: the Ministry of Health compels Sanlu to recall all products based on milk powder

23 September: the director of the AQSIQ resigns

17 October: the journal Science publishes Wen Jiabao's statement labelling the food contamination "impermissible"

23 October: the WHO criticises China's food safety system

\section{The experts are called in:}

20 September: Starbucks removes all milk products from its outlets 25 October: the Hong Kong Centre for Food Safety detects melamine in eggs imported from China

30 November: the US Food and Drug Administration offers assistance to the Chinese government

21 December: Cadbury recalls 11 milk products made in China

\section{The legal proceedings:}

24 December: Sanlu files for bankruptcy

26 December: the trial of Tian Wenhua and 20 other defendants opens in Shijiazhuang

14 January: the parents of the first official victim of melamine poisoning accept Sanlu's compensation package

19 January: 213 families with sick children lodge their complaint with the Supreme Court in Beijing

22 January: Tian Wenhua receives a life sentence, and three melamine manufacturers get the death penalty. 